\title{
Analysis of Beads and Pendants
}

\author{
Jolanda Bos and Vanessa Davies
}

\section{Introduction}

The beads and pendants from the excavations that Arthur Mace conducted under George Reisner in the Naga ed-Deir cemeteries N 2000 and N 2500 were one of the object categories that were abundantly present in the tombs. The beads and pendants were made from a variety of materials, including Egyptian faience, ostrich shell, stone, and metal. On first glance, the bead repertoire is typical for the periods they represent (Old Kingdom/First Intermediate Period). This chapter summarizes the evidence from cemeteries $\mathrm{N} 2000$ and $\mathrm{N} 2500$ and complements the catalogue of the beads and pendants. Due to the restrictions in the documentation of Mace, certain spatial statistical evaluation of the beads and pendants may no longer be possible.

\section{$2 \quad$ Research Method}

The most complete Naga ed-Deir typology is that of the Dynasty 3 through 6 beads and pendants from cemeteries $\mathrm{N}$ 500-90o. ${ }^{1}$ Some of the material here was also presented in that volume of Reisner's. Much of this current analysis was done by Andrea Miloslavic and Jocelyn Simlick, with Vanessa Davies. They catalogued the beads according to shape, color, material, dimensions, and surface treatment. In total, approximately 17,00o objects were examined, made from 18 different kinds of materials.

For this analysis, the Xia publication on ancient Egyptian beads was used to understand the Naga ed-Deir bead repertoire. The percentages of different materials and shapes were used to date the burials, which correspond to burial dates derived from the material described in the tomb catalogue. A difficulty that should be taken into account, however, when drawing conclusions from analyzing the materials of a bead corpus is that Harrell pointed out that the analysis of different materials in the archaeological stone bead repertoire has

1 Reisner 1932, 105-153. 
TABLE 8.1 Distribution of materials

\begin{tabular}{|c|c|c|c|}
\hline Materials & Number & $\begin{array}{l}\% \text { of the } \\
\text { repertoire }\end{array}$ & $\begin{array}{l}\text { Total number of tombs in which } \\
\text { material appears }\end{array}$ \\
\hline Faience & 11,530 & $68 \%$ & $\begin{array}{l}18(\mathrm{~N} 2010,2016,2021,2031 \\
2042,2071,2072,2075,2090 \\
2092,2105,2212,2235,2292 \\
2432,2434,2521,2834)\end{array}$ \\
\hline Ostrich eggshell & 3,504 & $21 \%$ & 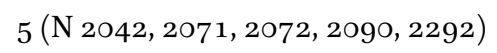 \\
\hline Mud & 927 & $0.06 \%$ & $3(\mathrm{~N} \mathrm{2042,2071,2235)}$ \\
\hline Carnelian & 634 & $0.04 \%$ & $\begin{array}{l}12(\mathrm{~N} 2016,2021,2031,2042 \\
2071,2072,2075,2090,2105 \\
2212,2292,2521)\end{array}$ \\
\hline Steatite & 99 & o.oo6\% & $\begin{array}{l}10(\mathrm{~N} 2016,2021,2031,2071, \\
\left.2072,2075,2212,2239,2292,25^{21}\right)\end{array}$ \\
\hline $\begin{array}{l}\text { Faience covered in } \\
\text { gold }\end{array}$ & 74 & $0.004 \%$ & $1(\mathrm{~N} 2021)$ \\
\hline Shell & 20 & $0.001 \%$ & $5(\mathrm{~N} 2042,2071,2093,2212,2235)$ \\
\hline Green feldspar & 15 & $>0.001 \%$ & $4(\mathrm{~N} \mathrm{2O} 21,2031,2042,2291)$ \\
\hline Agate & 13 & $>0.001 \%$ & $3(\mathrm{~N} \mathrm{2021,2071,2075)}$ \\
\hline Amethyst & 9 & $>0.001 \%$ & $1(\mathrm{~N} 2 \mathrm{O} 42)$ \\
\hline Gold & 5 & $>0.001 \%$ & $3(\mathrm{~N} \mathrm{2016,2075,2618)}$ \\
\hline Quartz & 4 & $>0.001 \%$ & $4(\mathrm{~N} \mathrm{2042,} \mathrm{2071,} \mathrm{2072,} \mathrm{2075)}$ \\
\hline Seed & 3 & $>0.001 \%$ & $2(\mathrm{~N} 2071,2075)$ \\
\hline $\begin{array}{l}\text { Egyptian blue, glass, } \\
\text { metal }\end{array}$ & 2 each & $>0.001 \%$ & $\begin{array}{l}\text { Blue (N 2031, 2075); glass ( } 2071 \text {, } \\
\text { 2075); metal ( } 2031,2075)\end{array}$ \\
\hline $\begin{array}{l}\text { Coral(?), onyx, } \\
\text { travertine, unknown }\end{array}$ & 1 each & $>0.001 \%$ & $\begin{array}{l}\text { Coral (N 2235); onyx, unknown } \\
(\mathrm{N} 2031) \text {; travertine }(\mathrm{N} 2042)\end{array}$ \\
\hline Total & 16,847 & & \\
\hline
\end{tabular}

often been incorrectly determined. ${ }^{2}$ Although we acknowledge the fact that it is difficult to analyze the different stone types, a rough distinction between the materials is nonetheless given here. The attribution of material type was consequently done on the basis of visual inspection, and no invasive tests were done on this material. Color divisions were also done based on visual inspection. Classification of the beads was done using the publications of Xia,

2 Harrell 2017, 2. 
Beck, and Harrell. Objects were described using the terminology of Beck and Harrell and when possible were given a typological classification according to Xia's typology. ${ }^{3}$

The most common bead groupings buried with the individuals was faience $(68 \%)$ and ostrich eggshell $(21 \%)$. Xia Nai analyzed the variation of different materials used in the First Intermediate Period, finding a relatively low amount of carnelian when compared to the Old Kingdom and a relatively high amount of ostrich eggshell and faience. ${ }^{4}$ His analysis is in line with our findings, although the percentages of materials from the Naga ed-Deir bead corpus deviates from the percentages of Xia's bead corpus Xia. Xia also mentioned a decrease in glazed steatite and metal beads in the First Intermediate Period, although we do find metal (gold, 5 beads) and glazed steatite ( 98 beads in total). ${ }^{5}$ According to Xia, no amethyst was used in bead fabrication in the Old Kingdom repertoire in Reisner's earlier excavations at Naga ed-Deir, but this corpus contains several amethyst beads ( 9 in total). ${ }^{6}$

\section{3}

\section{Spatial Distribution}

In total, approximately 16,847 beads, pendants, and the like were uncovered from a total of 22 burials. Of those 22 burials, 19 are from the Dynastic era, 1 is Coptic, and 2 are undetermined, but probably also from the Dynastic era. The two undetermined burials are described only by Reisner's terse notes when he made a preliminary survey of $\mathrm{N} 2000$ and $\mathrm{N} 2500$ in 1901 . Beads were found in only $15 \%$ of excavated tombs from the Dynastic era. The total number of tombs from that time period in these cemeteries is 138 . Neither beads nor pendants were found in 117 tombs from the Dynastic era. Therefore, the main body of beads came from the 21 Dynastic-era tombs and 1 Coptic-era burial (N 2291). The amount of beads that were interred with the buried individuals varies between 1 ( $\mathrm{N} 2291)$ and 4,072 ( $\mathrm{N} 2090)$. The amount of pendants varies between 1 ( $\mathrm{N}_{2618}$ ) and 36 ( $\mathrm{N}$ 2021).

A clear connection between the graves containing beads and the sex of the individuals buried in those graves was not fully possible to determine due to the deterioration and disturbance of many of the human remains in the

\footnotetext{
3 Beck 2006, Part II; Harrell 2017, Table 2.

4 Xia 2014, 97.

5 Xia 2014, 97.

6 Xia 2014, 89 .
} 
Dynastic era burials. The following statements can be made. Beads were found in conjunction with the burials of two children (N 2071, 2092). The only Coptic burial that contained beads was of an adult male (N 2291). A bird amulet was found in the main chamber of a tomb that contained a burial in the side chamber that Mace questioningly identified as a male ( $\mathrm{N} 2618)$.

The date for most of these graves remains inconclusive although the majority of the tombs yielding the beads described here can be attributed to the (end of the) Old Kingdom or the First Intermediate Period. The distribution of burials containing beads and pendants across the cemetery is fairly even. Two tombs in column A on Mace's map contained these objects (A4: N 2075; A5: 2072), two tombs in column B (B4: N 2071; B5: 2042), five tombs in column C (C4: N 2291, 2292; C5: N 209o, 2092, 2093), eight tombs in column D (D3: $\mathrm{N}_{2432}$, 2834; D4: N 2010, 2016, 2105, 2239; D5: N 2212, 2618), and three tombs in column E (E3: $\mathrm{N}$ 2031, 2434; E4: $\mathrm{N} 2235$ ). The greater number of tombs containing beads and pendants in columns $\mathrm{C}$ and $\mathrm{D}$ corresponds to the higher concentration of burials in general in those two areas. The two tombs excavated by Reisner in 1901 (N 2021, 2521) are not on Mace's map, which is dated December 1904.

Among the tombs with the greatest variety of beads, pendants and the like are $\mathrm{N} 2042$, 2071, and 2090. Correspondingly, these tombs have among the largest number of those objects ( $\mathrm{N} 2042$ with 4,109 objects; N 2071 with 3,053 objects; $\mathrm{N} 2090$ with 4,073 objects). The burial in $\mathrm{N} 2031$ is notable because it contained fewer objects $(1,065)$, but those were made from a wide variety of materials, including steatite, green feldspar, onyx, metal, Egyptian blue, and an undetermined green opaque material, in addition to faience and carnelian, which were more commonly found in these cemeteries. A quantity of flakes of yellow gold was also found in $\mathrm{N}$ 2031. Two burials are significant because of the large number of amuletic/figural pendants found in them. $\mathrm{N} 2021$ contained 25 carnelian, 12 green feldspar, and 5 faience amuletic pendants, as well as a number of more commonly found beads and 74 faience beads covered in gold, the only ones to be found in these cemeteries. N 2016 contained 6 amuletic pendants made of faience and 3 in gold. Judging from the notes Mace made on these cemeteries, beads and pendants seem to be one of the most generally used prestige objects in the tombs.

Forms and dimensions of the beads are of course closely linked to the technology of bead manufacturing, the constraints of the material, and the consequential 
TABLE 8.2 Distribution of beads

\begin{tabular}{|c|c|c|c|}
\hline Tomb number & $\begin{array}{l}\text { Number of } \\
\text { beads }\end{array}$ & $\begin{array}{l}\text { Number of } \\
\text { pendants }\end{array}$ & Other \\
\hline $\mathrm{N} 2010$ & 41 & & \\
\hline $\mathrm{N} 2016$ & 12 & 4 & \\
\hline $\mathrm{N} 2021$ & 94 & 36 & \\
\hline $\mathrm{N} 2031$ & 1,065 & & \\
\hline $\mathrm{N} 2042$ & 4,102 & 7 & \\
\hline $\mathrm{N} 2071$ & 2,876 & 9 & $\begin{array}{l}3 \text { unperforated shells, } \\
190 \text { conical decorations }\end{array}$ \\
\hline $\mathrm{N} 2072$ & 545 & & \\
\hline N 2075 & 471 & & 1 seed \\
\hline N 2090 & 4,071 & 1 & \\
\hline $\mathrm{N} 2092$ & 1,076 & & \\
\hline N 2093 & & & 1 unperforated shell \\
\hline $\mathrm{N} 2105$ & 3 & & \\
\hline $\mathrm{N} 2212$ & 15 & 6 & \\
\hline $\mathrm{N} 2235$ & 1,149 & & 325 sequins \\
\hline N 2239 & 2 & & \\
\hline N 2291 & 1 & & \\
\hline $\mathrm{N} 2292$ & 215 & 1 & \\
\hline N 2432 & 36 & & \\
\hline N 2434 & $6 o$ & & \\
\hline $\mathrm{N} 2521$ & 426 & & \\
\hline $\mathrm{N} 2618$ & & 1 & \\
\hline $\mathrm{N} 2834$ & & 2 & \\
\hline $\begin{array}{l}\text { Subtotal } \\
\text { Total } 16,847\end{array}$ & 16,260 & 67 & $5^{20}$ \\
\hline
\end{tabular}

use of the objects. ${ }^{7}$ Many of the beads from this assemblage were made of faience or glazed material, ostrich shell, or stone. In the Naga ed-Deir cemeteries, ring beads were the most common type. Subtypes include barrel, biconical, and cylindrical. The second largest group consists of disc beads, also of barrel, biconical, and cylindrical subtypes. Another common bead type is barrel beads of short and long varieties. Xia mentions an increase in the appearance

7 Bar-Yosef 2013. 
TABLE 8.3 Distribution of shapes

\begin{tabular}{|c|c|c|c|}
\hline Shape & Number & $\begin{array}{l}\% \text { of the } \\
\text { repertoire }\end{array}$ & $\begin{array}{l}\text { Total number of tombs in which the } \\
\text { shape appears }\end{array}$ \\
\hline Ring & 8,890 & $53 \%$ & 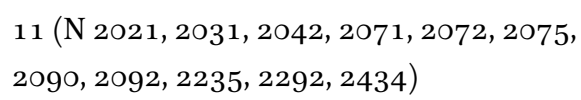 \\
\hline Disc & 6,291 & $37 \%$ & $\begin{array}{l}12(\mathrm{~N} 2010,2021,2031,2042,2071,2072, \\
\left.2075,2090,2292,2432,2434,25^{21}\right)\end{array}$ \\
\hline Barrel & 490 & $0.03 \%$ & 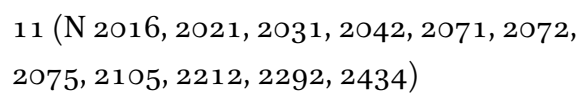 \\
\hline
\end{tabular}

of ring beads and a notable decrease in long beads in the First Intermediate Period, with an increase in spheroid beads at the expense of ring beads as the Middle Kingdom approaches. ${ }^{8} 90 \%$ of this corpus consists of ring beads and disc beads. The next most common shape, although not nearly as numerous as the ring and disc beads, are barrel beads. Other shapes found in N 2000/N 2500 are ball beads, figural objects, cylindrical beads, spacers, conical and biconical beads, and others, including non-bead items, such as mud sequins and mud conical decorations. According to Xia Nai and our understanding of the bead repertoire based on the spread of the bead types and materials, this Naga edDeir assemblage likely belongs to the First Intermediate Period. This is also obvious from the lack of a certain complexity in materials and shapes, which is often present in the Old and Middle Kingdom bead repertoires.

Two burials contained girdles that were wrapped around the body of the

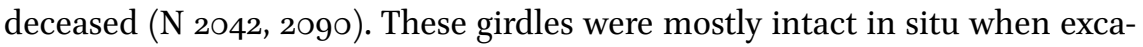
vated and consisted of green, black, and white disc and ring beads made of faience and ostrich eggshell. The following objects contain a large number of beads, and their presence in their respective tombs cause the amount of beads in those burials to increase considerably ( $\mathrm{N}$ 2031: necklace PAHMA 6-14317; $\mathrm{N}$ 2042: girdle PAHMA 6-14332, PAHMA 6-14341, PAHMA 6-14343; $\mathrm{N}$ 2090: girdle PAHMA 6-14397, PAHMA 6-14398, PAHMA 6-14399, PAHMA 6-1440O, PAHMA6-144O1,PAHMA6-144O2,PAH MA6-144O3,PAH MA6-144O4,PAHMA6-144O5, PAHMA 6-144O7; N 2092: necklace PAHMA 6-14410).

8 Xia 2014, 98. 
Some noteworthy pendants reinforce the general dates of burials. Three heh amulets executed in gold (PAHMA 6-14304a-c) were found in N 2016. These amulets are typical for the Old Kingdom, from Dynasty 6 onwards. The pendants are schematically executed and stylized, although the face, hair, and kilt are easily visible. The god Heh depicted there is shown holding a palm rib in each hand representing the hieroglyph for "years." In the First Intermediate Period and Middle Kingdom, these amulets appear more frequently, often executed in gold, copper, or faience, although the latter material goes hand in hand with less detailed examples. ${ }^{9}$ Five amulets in the Ashmolean Museum were found in the Hammamia tomb of a woman, arranged on her skull. ${ }^{10}$ Similar amulets were found at Abydos and date to the Middle Kingdom (MMA 04.16.6, 04.16.10, 04.16.11, 04.16.13, 04.16.14). Those amulets were excavated by the Egypt Exploration Fund in 1904 in Cemetery v, Tomb V21, although little information is known about the original arrangement of the jewelry items. ${ }^{11}$ The gold heh pendant in the Oriental Museum, University of Durham (EG 5072) shows a relatively well-executed figure in gold depicted with a long curved beard and tripartite wig and a disc on his head. That object dates to Dynasty 6, and the museum also has a mold in which objects like this could be produced. Three similar amulets (Brooklyn 13.1037, 13.1035, 13.1036) are possibly made of electrum and date to Dynasties 12 and 13. These stylized versions were excavated at Abydos from tomb D 303. A silver version of the pendant (MFA 13.3772), fairly large for this pendant type $(2.1 \mathrm{~cm})$ dates to the Middle Kingdom and was found close to Naga ed-Deir, at Sheikh Farag, in tomb sF 17o. All other known samples are approximately $1 \mathrm{~cm}$ in size. The general interpretation of these types of pendants is that the deceased buried with them will enjoy millions of years in the afterlife due to the association with the god Heh. Based on the similar finds from other cemeteries, the most likely date for the Naga ed-Deir burial containing the heh amulets is the First Intermediate Period or Middle Kingdom, although an Old Kingdom date cannot be ruled out.

A pendant in the shape of an ibis (PAH MA 6-14547) was discovered in N 2618. A parallel in the British Museum (EA 62460) dates to Dynasties 8 or 9 and was excavated at Mostagedda, grave 542. In the collection of the Hearst Museum, another similar pendant (PAH MA 6-22885) was also excavated at Naga ed-Deir,

9 O'Neill, O'Neill, and Allen 1999, 488.

10 O'Neill, O'Neill, and Allen 1999, 488.

11 Hayes 1953, 236. 
from cemetery $\mathrm{N} 3500$, tomb $\mathrm{N} 35^{26}$, dating to the end of the Old Kingdom. ${ }^{12}$ This type of pendant becomes more numerous at the beginning of the First

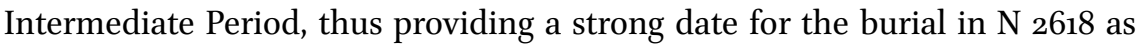
well. Most similar pendants are made of gold, electrum, or copper. Both examples in the collection of the Hearst Museum exhibit a poorly rendered bird beak. Additional indications that these two pendants date to the same time frame are the striking similarity in the manner in which the legs of both bird amulets are attached to the body and the attachment of the suspension ring. ${ }^{13}$

The dataset contained one mushroom-shaped glass pendant (PAHMA 6-14382) perforated along the long axis of the object. This type of pendant has been frequently identified as an ear-plug or ear-stud. In a forthcoming publication, however, Anna Hodgkinson reinterprets them and cautions not to take the interpretation as ear-plug for granted. These pendants could also have been worn as parts of larger jewelry pieces or may have been ornaments worn in the hair or wig since quite a large number of them had been pierced. ${ }^{14}$ The object dates to the New Kingdom, and the specific color scheme of this pendant suggests that the object dates to the Amarna period or slightly earlier or later. ${ }^{15}$ The fact that this object is part of this data set is remarkable, however, since the beads and pendants are mostly dated to the Dynastic era, mostly to the First Intermediate Period and Middle Kingdom.

Some other objects that are noteworthy are the ball beads with spiral black and white decoration (PAHMA 6-14358; PD3 according to the typology of Xia Nai). These balls most likely date to the Old Kingdom. However, the two glazed pendants shaped like an ankh sign and possibly an animal head (PAHMA 6-12515), both of which are very small (1.48-2.65 mm), suggest a New Kingdom date, likely similar to the mushroom-shaped pendant (PAHMA 6-14382).

\section{Beading Technology}

Most of the beads found in the cemeteries are small and were, most likely, produced to be threaded into necklaces or other jewelry items. This can be determined from the general shapes that make the beads fit for simple threading. Very few objects contain the original thread. Evidence of thread can be

\footnotetext{
12 Andrews 1994, Fig. 62.

13 O'Neill, O'Neill, and Allen 1999, 486.

14 Hodgkinson, forthcoming.

15 Personal communication with Dr. Anna Kathrin Hodgkinson.
} 


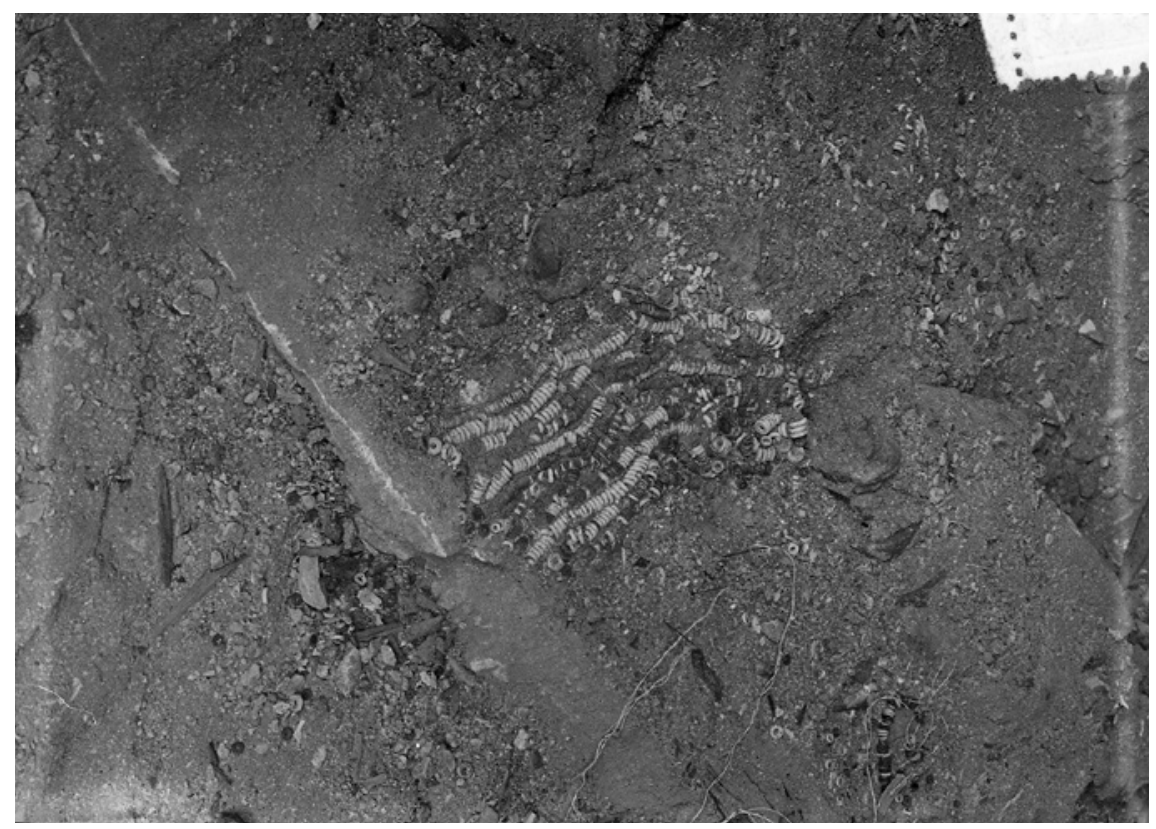

FIGURE 8.1 A portion of the girdle (6-14343) as found in situ (NED-C-75O2)

found inside the amethyst and faience beads of PAH MA 6-14336, the carnelian of PAHмA 6-14338, and some of the faience beads of РАнMA 6-14365.

Despite the fact that no single complete object exists as it would have in antiquity, one of the more remarkable objects, the so-called girdle (PAHMA 6-14332, PAHMA 6-14341, PAHMA 6-14343), can be reconstructed. The girdle, found in $\mathrm{N} 2042$, consisted of fifteen strings of white, green, and black beads that were threaded together in different interlacing chains. The beads have been rethreaded in modern times. Some beads that were once part of the girdle are now separated from it, so the pattern as preserved today does not entirely adhere to the original design. The excavation photographs provide our best evidence of the girdle's original patterning. What was used as the basis for the modern interpretation of the original pattern is unclear. Currently, the girdle is a netlike structure, $5^{6}$ centimeters in length that seems to mimic the original shape of the object based on the photographs of the object in situ (Fig. 8.1).

The other complex beaded object from the cemetery, the girdle found in $\mathrm{N}$ 209o, has been restrung in modern times as several separate objects. Based

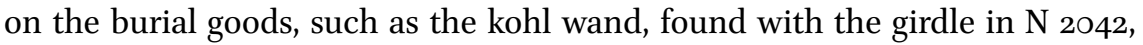
it may be that $\mathrm{N}_{2042}$ is a Middle Kingdom burial. Kohl sticks (if this is the excavator indicated by the word "wand") are said to appear after Dynasty 11, although no detailed analysis of this object type is available. A correlating fact is 
that beaded girdles are more often found in the Middle Kingdom. At Diospolis Parva, Petrie excavated a girdle of beadwork dating to Dynasties 6-8 that was "strung together irregularly," similar to the Naga ed-Deir girdle. The Diospolis Parva girdle is 10 inches long with rows of blue, black glaze, and shell beads sewn onto a material, possibly leather, which had deteriorated. ${ }^{16}$ The predominant beading technology in ancient Egypt is threading, and a netted beading technique would have been necessary for the production of the Naga ed-Deir girdle if the girdle was made without textile or leather support.

Other notable beads include the rolled faience (РAHMA 6-14303, N 2016), the faience beads covered in gold (PAHMA 6-14305, N 2021), the striped faience (PAHMA 6-14364, N 2071), the bubbly bead (PAHMA 6-14375, N 2071), and the scarab where the hole was not drilled uniformly through the center of the object (PAHMA 6-14372, N 2017).

\section{Amulets}

A large variety of amulet types were found in cemeteries $\mathrm{N} 2000$ and N 2500 . The following table summarizes those finds.

TABLE 8.4 Distribution of figural types

Figural type

Number \% of the Total number of tombs in repertoire which the figural type appears

\begin{tabular}{|c|c|c|c|}
\hline Lion & 12 & $12 \%$ & $\begin{array}{l}8(\mathrm{~N} 2016,2 \mathrm{O} 21,2042,2071, \\
2072,2212,2235,2834)\end{array}$ \\
\hline Full frontal face & 10 & $10 \%$ & $1(\mathrm{~N} 2 \mathrm{O} 21)$ \\
\hline Lion (crocodile/jackal?) head & 9 & $9 \%$ & $3(\mathrm{~N} \mathrm{2021}, 2212,2235)$ \\
\hline Fist & 6 & $6 \%$ & $1(\mathrm{~N} 2021)$ \\
\hline Door/ladder & 5 & $5 \%$ & $1(\mathrm{~N} 2071)$ \\
\hline Eye of Horus & 5 & $5 \%$ & $1(\mathrm{~N} 2 \mathrm{O} 21)$ \\
\hline Scarab & 5 & $5 \%$ & $1(\mathrm{~N} 2071)$ \\
\hline Shell & 5 & $5 \%$ & $3(\mathrm{~N} \mathrm{2021,2042,2071)}$ \\
\hline Lenticular (bead/pendant) & 4 & $4 \%$ & $2(\mathrm{~N} \mathrm{2071,2075)}$ \\
\hline Double lion head & 3 & $3 \%$ & $2(\mathrm{~N} \mathrm{2016,2071)}$ \\
\hline Falcon & 3 & $3 \%$ & $1(\mathrm{~N} \mathrm{2O21)}$ \\
\hline heh hieroglyph & 3 & $3 \%$ & $1(\mathrm{~N} 2016)$ \\
\hline
\end{tabular}

16 Petrie and Mace 19o1, 41; Xai 2014, 93. 
TABLE 8.4 Distribution of figural types (cont.)

Figural type

Paddle

Tawaret

Bee

Bes (?)

Fish

Scarab, winged

ankh

Double humped (sema tawy?)

djed pillar

Fly

Frog

Hippopotamus (?) head

Human (?)

Human with false beard

Ibis

Ihy/Khonsu/Shed (?)

Ox head (?)

Ram/ichneumon

Six-holed pendant

tj.t

was-scepter head

Unidentified

Total
Number \% of the Total number of tombs in repertoire which the figural type appears

\begin{tabular}{|c|c|c|}
\hline 3 & $3 \%$ & $3(\mathrm{~N} \mathrm{2016,2071,2212)}$ \\
\hline 3 & $3 \%$ & $3(\mathrm{~N} \mathrm{2016,2021,2212)}$ \\
\hline 2 & $2 \%$ & $1(\mathrm{~N} 2 \mathrm{O} 21)$ \\
\hline 2 & $2 \%$ & $1(\mathrm{~N} 2212)$ \\
\hline 2 & $2 \%$ & $2(\mathrm{~N} \mathrm{2O21,2031)}$ \\
\hline 2 & $2 \%$ & $1(\mathrm{~N} \mathrm{2071)}$ \\
\hline 1 & $1 \%$ & $1(\mathrm{~N} 2834)$ \\
\hline 1 & $1 \%$ & $1(\mathrm{~N} \mathrm{2O42)}$ \\
\hline 1 & $1 \%$ & $1(\mathrm{~N} 2090)$ \\
\hline 1 & $1 \%$ & $1(\mathrm{~N} 2075)$ \\
\hline 1 & $1 \%$ & $1(\mathrm{~N} 2212)$ \\
\hline 1 & $1 \%$ & $1(\mathrm{~N} 2031)$ \\
\hline 1 & $1 \%$ & $1(\mathrm{~N} \mathrm{2O42)}$ \\
\hline 1 & $1 \%$ & $1(\mathrm{~N} \mathrm{2042)}$ \\
\hline 1 & $1 \%$ & $1\left(\mathrm{~N}_{2} 618\right)$ \\
\hline 1 & $1 \%$ & $1(\mathrm{~N} 2016)$ \\
\hline 1 & $1 \%$ & $1(\mathrm{~N} 2071)$ \\
\hline 1 & $1 \%$ & $1(\mathrm{~N} 2071)$ \\
\hline 1 & $1 \%$ & $1(\mathrm{~N} 2071)$ \\
\hline 1 & $1 \%$ & $1(\mathrm{~N} 2235)$ \\
\hline 1 & $1 \%$ & $1(\mathrm{~N} 2212)$ \\
\hline & $1 \%$ & $1(\mathrm{~N} \mathrm{2212})$ \\
\hline
\end{tabular}

By far the most common figure represented in this corpus, accounting for $24 \%$ of the total number of figural items, was the lion, whether complete, the head, or a double lion. The shape referred to as a lion head was identified by Brunton as lion/dog head and by Petrie as a jackal head. ${ }^{17}$ Regarding UC 38551, The Petrie Museum's online catalogue identifies the shape as a "jackal (or crocodile?) head." Because of the large number of lions in N 2000 and N 2500, we have chosen to follow the identification of the head as a lion. According

17 Brunton 1928, pl. 95:16; Petrie 1914, 13. 
to Brunton, these forms are found from Dynasties 4 through 11, placing them squarely in the date range typical for earlier burials in $\mathrm{N} 2000$ and $\mathrm{N} 2500$.

\section{$8 \quad$ Results}

The bead and pendant assemblages from the $\mathrm{N} 2000$ and $\mathrm{N} 2500$ cemeteries of Naga ed-Deir were common and most likely date to the late Old Kingdom/ First Intermediate Period and possibly the Early Middle Kingdom with the exception of the few New Kingdom outliers mentioned above. The majority of the beads were made of faience and were probably all made to be threaded into simple, one strand beadwork and/or necklaces, although more complex bead structures, such as the girdle, were excavated. When discussing the character of this period's beadwork, Xia described necklaces in which the spacing of larger beads was done by groups of ring beads, strings of ring beads with cylindrical beads, and amulets or scarab pendants as a centerpiece. ${ }^{18}$ These kinds of strands are also found in the $\mathrm{N} 2000$ and $\mathrm{N} 2500$ cemeteries (restrung) beadwork.

It should be noted that some of the objects described in the Seals and Sealings chapter might have been included here among the corpus of beads. The distinction between a seal and a bead was made largely on whether or not the object was strung since it was thought that the strung assemblages, although strung in modern times, reflected what the excavators thought the object's purpose was. For example, some strung necklaces included in this corpus contain scarabs (PAHMA 6-14367, PAHMA 6-14372) that, had they not been strung, would likely have been included in the other corpus. Likewise, the scarabs treated in Emily Teeter's chapter (PAHMA 6-14348, PAHMA 6-14363, PAнма 6-14374, PAнма 6-14383) would have been included here had they formed part of a necklace. The same is true of the small green faience square (PAHMA 6-14328) bored through the center to be strung.

The majority of the beads were most likely manufactured in workshops, where the stone beads were fabricated and glazed. Xia commented on the limited variety of materials used in bead production, and that limited variety is evident in cemeteries $\mathrm{N} 2000$ and $\mathrm{N} 2500$, although his stated reason, the social disorder at that time, is not necessarily, in the view of these authors, the cause. ${ }^{19}$

\footnotetext{
18 Xia 2014, 101.
}

19 Xia 2014, 97. 


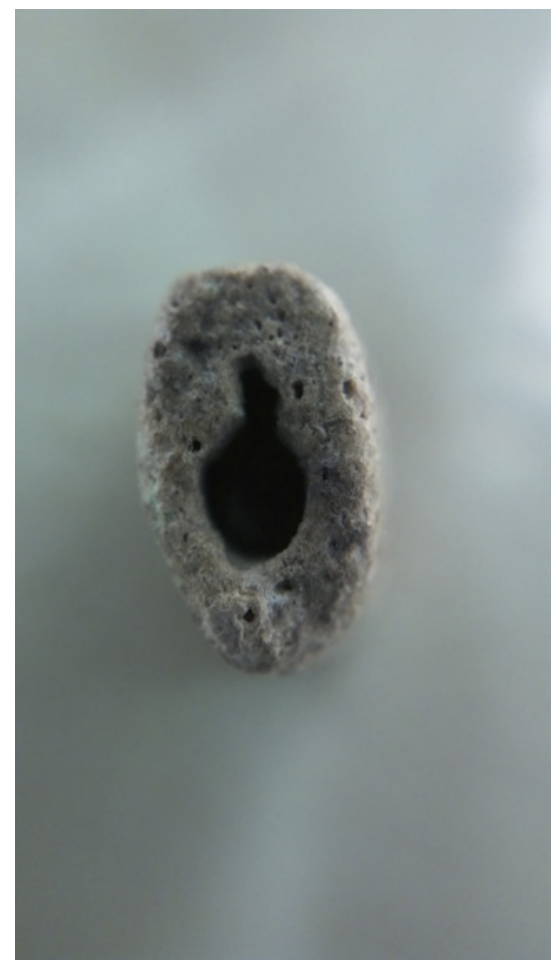

FIGURE 8.2

The divot in the aperture of a faience bead (part of the 6-14377 object number)

PHOTO BY ANDREA MILOSLAVIC

In an earlier Naga ed-Deir publication, Reisner noted that the edges of the faience and most of the carnelian ring and disc beads were rounded. ${ }^{20}$ This brings us to a lacuna in the bead analysis from ancient Egypt: use-wear analysis. Use-wear analysis has, for instance, been done by Annelou van Gijn. ${ }^{21}$ It would be interesting for future research to study both the typical wear marks revealing more information on the use of these beads as well as explain the typical edges of the beads.

In this corpus, wear patterns can be seen on a number of objects. In the aperture of one of the faience beads in the grouping PAHMA 6-14377, a sharp divot suggests that the bead repeatedly rubbed on a string (Fig. 8.2). A number of the carnelian beads in PAHMA 6-14378 have small chips on their exterior edges and rounded surfaces. These could have occurred because the beads banged up against hard objects, perhaps other stone beads, while being worn, or they could have occurred in modern times. A more likely sign of ancient wear is a carnelian bead in PAHMA 6-1439o. The very small chips all along the

\footnotetext{
$20 \quad$ Reisner 1932, 149.

21 See, for example, Van Gijn 2014.
} 


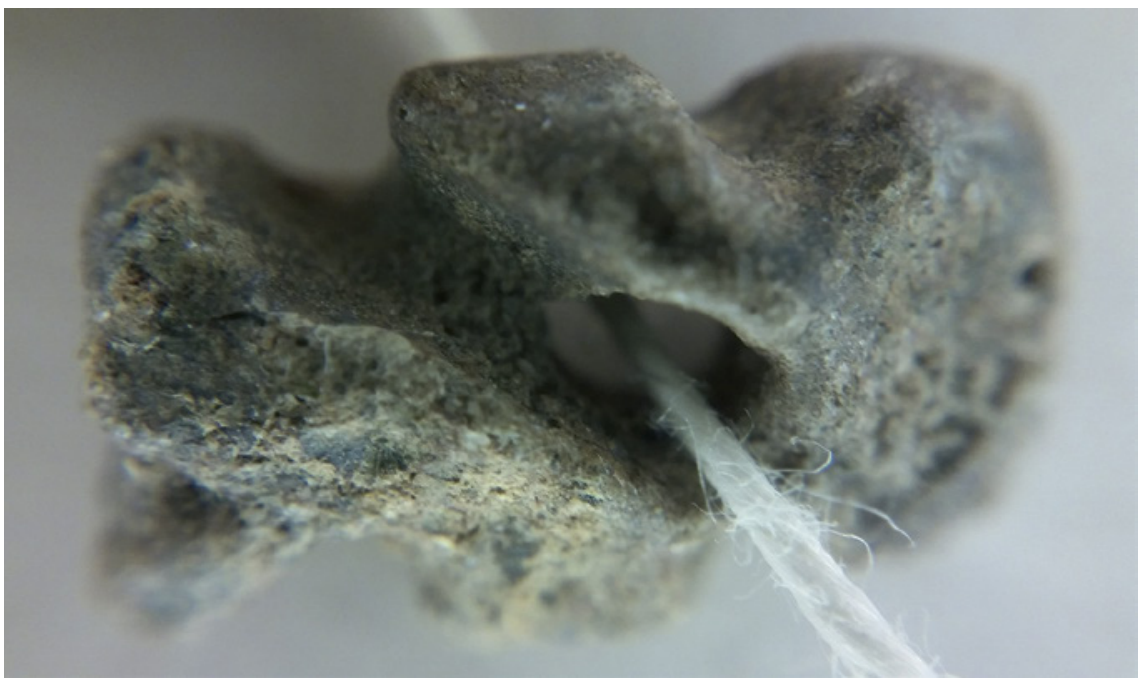

FIGURE 8.3 A deep groove on a tjt amulet (6-14462) suggests repeated rubbing against a string. PHOTO BY JOCELYN SIMLICK

outer aperture of that bead are indicative of the bead edge repeatedly knocking against another hard bead. The edges of the cylindrical and square beads of PAHMA 6-14459 show evidence of damage from wear, where small chips have been removed from the surface edge of the beads. Finally, a spacer and a tjt amulet in PAHмA 6-14462 contain deep grooves on their outer surfaces where those surfaces have repeatedly rubbed up against a string (Fig. 8.3). For more detailed analysis of the wear pattern, however, the material should be compared microscopically to similar materials and wear marks on other beads.

\section{Bibliography}

Andrews, C. 1994. Amulets of Ancient Egypt. Austin.

Bar-Yosef, M. 2013. "Towards a Typology of Stone Beads in the Neolithic Levant." Journal of Field Archaeology 38(2): 129-142.

Beck, H. C. 2006. "Classification and Nomenclature of Beads and Pendant." BEADS: Journal of the Society of Bead Researchers 18: 1-76. Available at: http://surface.syr .edu/beads/voli8/iss1/4.

Brunton, G. 1928. Qau and Badari II. London.

Falci, Catarina Guzzo, Annelou Van Gijn, M. Magdalena Antczak, Andrzej T. Antczak, and Corinne L. Hofman. 2016. "Challenges for microwear analysis of figurative shell ornaments from pre-Colonial Venezuela." Journal of Archaeological Science: Reports 11 (2017): 115-130. 
Harrell, J. A. 2017. "A Preliminary Overview of Ancient Egyptian Stone Beads." PalArch's Journal of Archaeology of Egypt/Egyptology 14(2) (tEBP Series): 1-16.

Hayes, W. C. 1953. Scepter of Egypt I: A Background for the Study of the Egyptian Antiquities in The Metropolitan Museum of Art: From the Earliest Times to the End of the Middle Kingdom. Cambridge, MA.

Hodgkinson, A. K. Forthcoming. "Ear-plugs, Ear-studs or Beads? Reinterpreting a Group of New Kingdom Glass Objects in the British Museum." British Museum Studies in Ancient Egypt and Sudan.

O'Neill, A., J. P. O'Neill, J. Allen. 1999. Egyptian Art in the Age of the Pyramids. New York.

Petrie, W. M. F. 1914. Amulets, illustrated by the Egyptian Collection in the University College, London. London.

Petrie, W. M. F. and A. C. Mace. 1901. Diospolis Parva, The Cemeteries of Abadiyeh and $H u, 1898-9$. London.

Reisner, G. A. 1932. A Provincial Cemetery of the Pyramid Age, Naga-ed-Dêr Part III. University of California Publications, Egyptian Archaeology 6. Berkeley.

Van Gijn, A. L. 2014. "Science and Interpretation in Microwear Studies." Journal of Archaeological Science 48: 166-169.

Xia, N. 2014. Ancient Egyptian Beads. Beijing. Dor: 10.1007/978-3-642-54868-o. 